\title{
Zikavirusinfeksjon er farligst i første trimester
}

\section{Risiko for fosterskade ved zika- virusinfeksjon er særlig høy ved smitte tidlig i svangerskapet.}

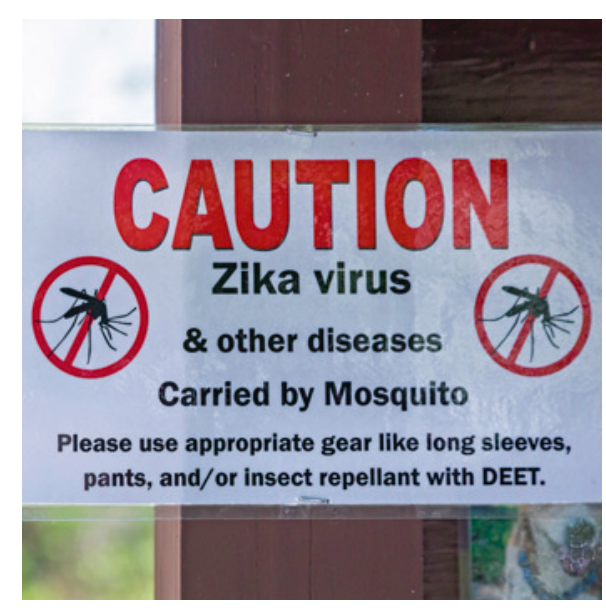

Advarsel om zikavirus. Foto: Science Photo Library
Det har tidligere vært anslått at andelen gravide mødre med zikavirusinfeksjon som får barn med mikrokefali er relativ lav, det vil si mellom $1 \%$ og $13 \%$ (1). En ny studie av 442 amerikanske gravide med blodprøver som indikerte nysmitte med zikavirus viser at om lag $6 \%$ fødte barn med skader kunne relateres til zikavirusinfeksjon (2). Det var ingen forskjell $\mathrm{i}$ andel fosterskader når man sammenlignet gravide med symptomatisk infeksjon med gravide med asymptomatisk infeksjon.

De 26 fostrene/barna som ble født med fosterskade som følge av zikavirus, hadde mikrokefali $(n=4)$, mikrokefali og hjerneabnormiteter $(n=14)$ eller hjerneabnormiteter uten mikrokefali $(n=4)$. Av de 85 gravide som hadde symptomer eller smitteeksponering bare i første trimester, fikk ni av deres barn fosterskader. Ingen kvinner som ble eksponert for zikavirus $\mathrm{i}$ annet eller tredje trimester, fikk barn med fosterskader.

- Andelen barn født med skader etter zikavirusinfeksjon var som forventet høy, sier forsker Mari Kaarbø, som leder Virologisk forskningsgruppe ved Oslo universitetssykehus.

- Denne studien bekrefter at risikoen for å få barn med zikavirusrelaterte skader er den samme enten infeksjonen hos moren gir symptomer eller ikke. Dette viser at screening er viktig. Screening bør omfatte alle gravide kvinner som har oppholdt seg i høyrisikoområder, og kvinner som er blitt gravide med menn som har oppholdt seg i høyrisikoområder, sier Kaarbø, som understreker at studien er basert på preliminære data og har flere metodiske svakheter.

\section{Petter Morten Pettersen \\ Tidsskriftet}

\section{Litteratur}

1. Johansson MA, Mier-y-Teran-Romero L, Reefhuis $J$ et al. Zika and the risk of microcephaly. N Engl J Med 2016; 375: 1-4

2. Honein MA, Dawson AL, Petersen EE et al. Birth Defects Among Fetuses and Infants of US Women With Evidence of Possible Zika Virus Infection During Pregnancy. JAMA 2017; 317: 59-68.

\section{Kreftceller kan gjemme seg i fettvev}

\author{
Stamceller for leukemi søker seg til fettvev, der de får næring og blir \\ beskyttet mot kjemoterapi. Dette viser studier med en musemodell \\ for kronisk myeloid leukemi.
}

Ved bruk av fluoreserende markører er det nylig vist at kreftstamceller for leukemi i mus samler seg i gonadefettvev (1). Transkriptomundersøkelser av kreftstamcellene viste et sterkt oppregulert uttrykk av proinflammatoriske cytokiner og chemokiner.

Det ble dessuten påvist et høyere nivå av fettsyreoksidering i cellene, noe som kan ha sammenheng med at en subpopulasjon av kreftstamcellene var positive for CD36, et fettsyretransportprotein som bidrar til opptak av fettsyrer. In vitro- og in vivo-målinger viste økt resistens mot kjemoterapi og respirasjonshemmende legemidler. Tap av CD36positive stamceller førte til færre kreftstamceller i gonadefettvev og høyere sensitivitet for kjemoterapi.

- De siste tiårene er det gjort mange studier for å forstå heterogeniteten av leukemiceller og for å finne selektive, terapeutiske mål for behandling som kan utrydde cellen som er ansvarlig for sykdommens opprinnelse og utbredelse, nemlig leukemiske stamceller, sier Lorena Arranz, forsker ved Norsk senter for molekylærmedisin og gruppeleder ved Det helsevitenskaplige fakultet, Universitetet i Troms $\varnothing$ - Norges arktiske universitet.

- Studien utvider vår kunnskap ved å vise berikelse av leukemiske stamceller i fettvev og at CD36-protein kan være involvert ved terapiresistens for kjemoterapeutika. Den viser på en elegant måte at tap av CD36-protein gjør leukemiske celler sensitive til kjemoterapi. Dette innebærer ikke at det nødvendigvis vil være slik i klinisk sammenheng, mener Arranz.

- En svakhet ved studien er bruken av retrovirale vektorer for å modellere sykdom hvor transgenets kopiantall og plassering i genomet ikke er kontrollert fullt ut. Dette kan bidra til forskjeller observert hos pasienter og reiser spørsmål om den aktuelle mekanismen er til stede ved sykdom hos mennesker. Dessuten er noen av dataene vanskelig å tolke på grunn av den altfor vide definisjonen av leukemiske stamceller til å omfatte både opphav og forløpere. Ulike andeler av celler kan stå for ulike funksjoner. Til tross for disse svakhetene åpner studien nye veier for forskning, sier Arranz.

\section{Ruth Halsne}

Tidsskriftet

\section{Litteratur}

1. Ye H, Adane B, Khan N et al. Leukemic Stem Cells Evade Chemotherapy by Metabolic Adaptation to an Adipose Tissue Niche. Cell Stem Cell 2016; 19: an $23-37$.

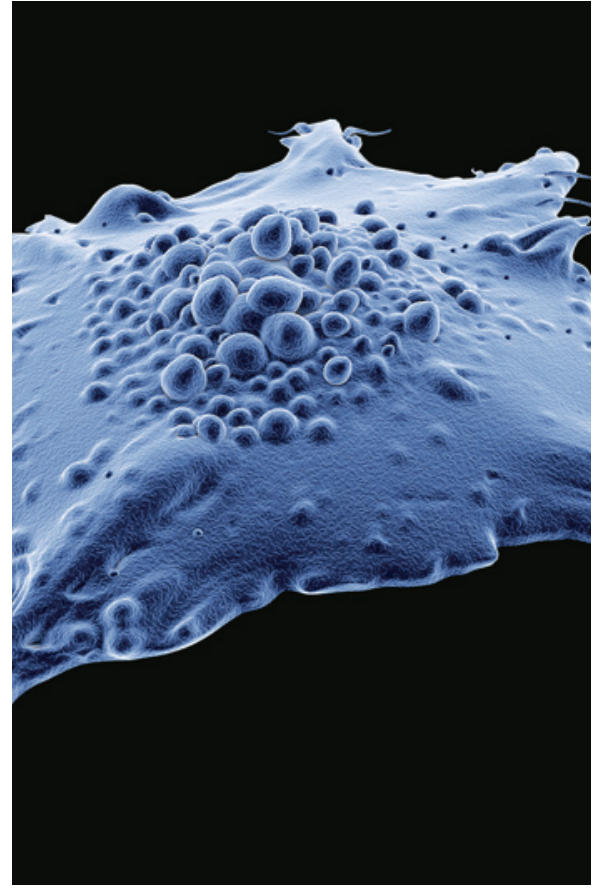

Kreftcelle. Illustrasjon: Science Photo Library 